\title{
Automated irrigation systems for wheat and tomato crops in arid regions
}

\author{
Hussein M Al-Ghobari', Fawzi S Mohammad' ${ }^{1}$, Mohamed SA El Marazky',2* and Ahmed Zakaria Dewidar ${ }^{1,2}$ \\ 'Department of Agricultural Engineering, College of Food and Agriculture Sciences, King Saud University, Riyadh 11451, Kingdom of Saudi Arabia \\ ${ }^{2}$ Agricultural Engineering Research Institute (AEnRI), Agricultural Research Centre, P.O. Box 256, Giza, Egypt
}

\begin{abstract}
Automated irrigation systems (AISs) are critical for the sustainability of irrigated farming systems, considering the present water crisis in Saudi Arabia. This study investigated whether electronic controllers in irrigation systems effectively save water. The study also assessed the effect of these controllers on crop yield using drip and sprinkler irrigation systems in severely arid climate conditions. Evapotranspiration (ET) controllers were installed in experimental fields of wheat (Triticum aestivum) and tomato (Solanum lycopersicum Mill.) crops for 2 successive seasons. The results revealed that the water use efficiency (WUE) and irrigation water use efficiency (IWUE) were typically higher in the AIS than in the conventional irrigation control system (CIS). Under the AIS treatment, the WUE and IWUE values were 1.64 and $1.37 \mathrm{k} \cdot \mathrm{gm}-3$ for wheat, and 7.50 and $6.50 \mathrm{~kg} \cdot \mathrm{m}-3$ for tomato crops; under the CIS treatment the values were 1.47 and $1.21 \mathrm{~kg} \cdot \mathrm{m}-3$ for wheat and 5.72 and $4.70 \mathrm{~kg} \cdot \mathrm{m}-3$ for tomatoes, respectively. Therefore, the AIS provided significant advantages in both water savings and crop yields by utilising up to $26 \%$ less water than the CIS, and simultaneously generating higher total yields. The automated irrigation system technique may be a valuable tool for conserving water and scheduling irrigation for wheat and tomato crops, and may be extendable to other similar agricultural crops.
\end{abstract}

Keywords: autonomous control, evapotranspiration controller, water conservation, sprinkler and drip irrigation, water-use efficiency, arid regions

\section{INTRODUCTION}

There is a great need to modernize agricultural practices for better water productivity and resource conservation. Efficient water management is a major concern in precision irrigation practices. The use of automated irrigation systems can provide water on a real-time basis at the root zone, based on the availability of soil water at the crop root zone, which also leads to saving of water (Ojha et al., 2015). Although the majority of crops are grown with irrigation systems, drip and sprinkler irrigation are increasing in popularity because of superior water application efficiency and more precise irrigation management. Automated irrigation systems allow for high-frequency irrigation, thus maintaining the soil water potential (SWP) relatively constant, compared to conventional irrigation systems. Many methods have been described and sensors developed to manage irrigation systems effectively (Yildirim, 2010).

Irrigation scheduling remains a reliable technique for applying the required amount of water at the appropriate time, and automated irrigation systems based on crop water needs can maximize WUE (Munoz-Carpena et al., 2005). The Technology Committee of the Irrigation Association (Irrigation Association, 2011) defines 'smart controllers' as the technologies that estimate or measure the depletion of soil moisture in order to replenish water as needed. Smart irrigation controllers $\left(\mathrm{SIC}_{\mathrm{S}}\right)$ can integrate information from numerous sources to significantly improve crop production and resource management (Norum and Adhikari, 2009). ET controllers are also used to automate irrigation and crop needs. This technology,

*To whom all correspondence should be addressed.

e-mail: melmarazky@ksu.edu.sa; elmarazky58@gmail.com

Received 29 May 2016; accepted in revised form 27 March 2017 sometimes referred to as 'smart technology' (McCready et al., 2009), provides irrigation based on actual water requirements and crop use and also takes weather factors into account. There are generally 2 types of smart controllers: climatological controllers, also called evapotranspiration (ET) controllers, and soil moisture sensor controllers (Dukes, 2102). Irrigation scheduling is a technique designed to water crops in a timely and accurate fashion (Schlegel et al., 2012). Irrigation scheduling tools allow producers to effectively manage water resources for crop production (Hayashi et al., 2012). Recent developments in agricultural technologies, such as wireless sensor networks which have sensing, data processing, communication and control capabilities (Zhang et al., 2013), are improving real-time irrigation efficiency (Smarsly, 2013). To be beneficial, these tools need to be accurate, complete and relatively reliable (Mun et al., 2015). However, the use of more efficient technologies often increases, rather than decreases, water consumption (Whittlesey, 2003). Efficient irrigation management is challenging owing to the number of factors that need to be considered, including climate, crop type, irrigation method and system parameters (Dabach et al., 2013). Improved irrigation scheduling can reduce irrigation costs and increase crop quality. Irrigation scheduling based on the crop water status is more advantageous as crops respond to both the soil and aerial environments (Yazar et al., 1999).

Drip irrigation has been practised for many years as it effectively reduces soil surface evaporation. Uniform water application in drip irrigation is affected by field topography and by the hydraulic design parameters of the drip system, such as the energy losses in the laterals and the emitter characteristics (Zhu et al., 2009). Furthermore, proper scheduling of sprinkler irrigation is critical for efficient water management in crop production, particularly under conditions of water scarcity (Pereira et al., 2002). The amount of sprinkler irrigation water 
used, the irrigation frequency and the water use strongly affect yields (Sezen and Yazar, 2006). A sprinkler irrigation system can play a significant role in increasing the water productivity of wheat in arid and semi-arid regions (Motazar and Sadeghi, 2008).

An automated irrigation system is integrated with electronic controllers and uses microclimate data to schedule water irrigation. The aim of the technique is to save water and reduce non-point-source pollution (Nautiyal et al., 2010). Automated irrigation technologies were evaluated in Dookie, Egypt, and were shown to result in water conservation of up to $38 \%$ over that of conventional irrigation (Dassanayake et al. 2009). The current trend in techniques for conserving water and energy in agriculture is to switch from a manual system to automatic operations in a pressurised system (Yildirim and Demirel, 2011). Through the use of sensors, different variables can be measured in real time, eliminating the problem of discontinuous field measurements (Acevedo-Opazoet et al., 2010), which is a key issue in precise irrigation management.

Irrigation scheduling using new technology contributes to higher water savings and water use efficiency in comparison with conventional irrigation scheduling methods, when it is designed, maintained and used properly (Mulas, 1986). Automated irrigation systems also facilitate high-frequency and low-volume irrigation (Abraham et al., 2000), and reduce human error (Castanon, 1992). An automatic irrigation control system can potentially optimise water management by sensing soil water conditions and site-specifically controlling irrigation methods (sprinkler vs. drip irrigation). Recent technological advances have made soil water sensors available for the efficient and automatic operation of irrigation systems (Dukes et al., 2010). Researchers have proposed using automated irrigation systems for remote infield sensing and variable-rate irrigation control (Kim et al., 2008). Such a system requires the seamless integration of input and output components, and a software program for decision support and monitoring. A number of studies have focused on increasing irrigation efficiency in automated irrigation systems (Muñoz-Carpena and Dukes, 2005).

Irrigation scheduling using new technologies contributes to higher water savings and water-use efficiency in comparison with the conventional irrigation scheduling methods, when it is designed, maintained, and used properly (Mulas, 1986). Automated irrigation systems also facilitate high-frequency and low-volume irrigation (Abraham et al., 2000). An automatic irrigation control system can potentially optimise water management by sensing soil water conditions and site-specifically controlling irrigation methods (sprinkler vs. drip irrigation). Recent technological advances have made soil water sensors available for the efficient and automatic operation of irrigation systems (Dukes et al., 2010). Researchers have proposed using automated irrigation systems for remote infield sensing and variable-rate irrigation control (Kim et al., 2008). Such systems require the seamless integration of input and output components, and a software program for decision support and monitoring. A number of studies have focused on increasing irrigation efficiency in automated irrigation systems (MuñozCarpena and Dukes, 2005).

In the past 10 years, electrical irrigation controllers have been developed by a number of manufacturers and have been promoted by water purveyors in an attempt to reduce overirrigation (Davis and Dukes, 2016). There are several irrigation controllers that can compute the amount of water applied based on ET and climate conditions (McCready et al., 2009). These systems differ in their accuracy and reliability; however, they all depend on modern electronic sensors, which are capable of collecting and analysing data, and making decisions on when to start/stop irrigation. These devices transmit the decisions to electronic controller devices, which control the sprinkler or drip irrigation system. This study investigated the effectiveness of automated irrigation systems for improving water saving and crop yield for wheat and tomato crops using both sprinkler and drip irrigation systems.

\section{MATERIALS AND METHODS}

\section{Experimental site}

Field experiments were performed during the 2013/2014 and 2014/2015 winter/spring seasons at the King Saud University Experimental Farm of the College of Food and Agriculture Sciences, Riyadh $\left(24^{\circ} 43 \rrbracket \mathrm{N}\right.$ latitude, $46^{\circ} 43 \rrbracket \mathrm{E}$ longitude and $635 \mathrm{~m}$ altitude). The soil consisted of $72.60 \%$ sand, $12.75 \%$ silt, $14.65 \%$ clay in the upper $60 \mathrm{~cm}$ soil profile, and could be classified as sandy loam. The bulk density varied from 1.59 to $1.64 \mathrm{~g} \cdot \mathrm{cm}^{-3}$. The available water-holding capacity within $60 \mathrm{~cm}$ of the soil profile was $15.97 \mathrm{~m}^{3} \cdot \mathrm{m}^{-3}$. Additional physical properties of the experimental soil are listed in Table 1.

\section{Field layout}

The study site was divided into 2 main fields, each divided into 2 plots (Fig. 1). One field was allocated to wheat and the other to tomatoes. In each field, one of the plots was irrigated

\begin{tabular}{|l|l|c|c|c|c|}
\hline \multicolumn{7}{|c|}{ TABLE 1 } \\
\hline \multicolumn{2}{|c|}{ Physical characteristic of different soil layers } \\
\hline \multirow{2}{*}{ Soil layer depth $(\mathbf{c m})$} & $\mathbf{0 - 2 0}$ & $\mathbf{2 0 - 3 0}$ & $\mathbf{3 0 - 6 0}$ & Average \\
\hline \multirow{2}{*}{ PSD $^{*}(\%)$} & Sand & 74.81 & 72.64 & 70.35 & 72.60 \\
\cline { 2 - 6 } & Silt & 11.77 & 11.65 & 14.82 & 12.75 \\
\cline { 2 - 6 } & Clay & 13.42 & 15.71 & 14.83 & 14.65 \\
\hline \multicolumn{2}{|c|}{ Soil texture class } & Sandy loam & Sandy loam & Sandy loam & Sandy loam \\
\hline Field capacity $\left(\mathrm{m}^{3} \mathrm{~m}^{-3}\right)$ & 14.74 & 17.27 & 15.90 & 15.97 \\
\hline Permanent wilting point $\left(\mathrm{m}^{3} \mathrm{~m}^{-3}\right)$ & 5.32 & 6.54 & 6.58 & 6.15 \\
\hline Bulk density $\left(\mathrm{gcm}^{-3}\right)$ & 1.64 & 1.61 & 1.59 & 1.61 \\
\hline
\end{tabular}

${ }^{*} P S D$ : particle size distribution (\%) 
automatically with the AIS, whereas the other was irrigated conventionally with a CIS, based on the crop evapotranspiration $\left(E T_{c}\right)$ values calculated from the meteorological data provided by the weather station. Solid sprinkler and drip irrigation systems were installed in both fields. Sprinkler systems were used for wheat crops, whereas drip irrigation systems were used to irrigate the tomato crops.

For the sprinkler irrigation treatment, a $10 \mathrm{~m}$ wide strip of land was used as a buffer zone between the AIS and the CIS plots. Solid sprinkler irrigation systems were installed in both wheat plots. Each plot consisted of 8 sprinklers to cover a cultivated area of $24 \times 9 \mathrm{~m}\left(216 \mathrm{~m}^{2}\right)$. The distance between the sprinklers was $8 \mathrm{~m}$, and the distance between the lines was $9 \mathrm{~m}$. The sprinkler system was designed and installed for each field plot with PVC laterals, and was connected to sub-main and main pipes. The sprinkler heads were fitted on the top of the sprinkler risers, which were galvanised steel pipes.

For the drip irrigation treatment, the site was also divided into 2 equal plots with a $5 \mathrm{~m}$ buffer in the middle. Each plot was approximately $7.2 \mathrm{~m}$ wide and $12 \mathrm{~m}$ long $\left(86.4 \mathrm{~m}^{2}\right)$, and had 9 rows of drip lines spaced $0.8 \mathrm{~m}$ apart, running from west to east. Tomato plants were spaced $0.40 \mathrm{~m}$ apart in each row, and the 9 drip lines in each plot were connected to a common submain irrigation line at the inlet side of the plot, and a common flush line and flush valve at the distal end of the plot. The drip irrigation systems consisted of thin-wall drip lines of a $16 \mathrm{~mm}$ inside diameter (ID) with welded-on emitters (Eurodrip GR, 40 $\mathrm{cm}$ dripper spacing), with a nominal emitter discharge of $4 \mathrm{~L} \cdot \mathrm{h}^{-1}$ at a design pressure of $200 \mathrm{kPa}$.

These irrigation systems were designed to achieve high performance and uniform water distribution. Each system was equipped with controllers to control the pressure and a flow meter to measure the water added during each irrigation event. The sprinkler and drip systems were evaluated in the field according to the methodology of Merriam and Keller (1978) and the ASABE Standard, S436.1 (2007). Each irrigation system was evaluated with the appropriate performance indexes under operating field conditions. All index values were found to be within acceptable limits, representing good water distribution uniformity (over 90\%). For comparison purposes, the experimental plots of the CIS were used.

\section{Components of the automated irrigation system}

The automated irrigation system chosen for this study was the (Hunter Pro-C) ET System. The controllers integrate many components to significantly improve crop production and resource management (Norum and Adhikari, 2009). This system is not considered to be the most effective; however, it was inexpensive and available in the local market. The AIS was installed in the experimental field according to manufacturer instructions. It can be customised by station (or 'zone') for specific plants, soils, and drip types.

This type of system uses digital electronic controllers and modules, and its platform can be wired to an ET module that can sense the local climatic conditions via sensors that measure wind speed, rainfall, solar radiation, air temperature, and relative humidity. The ET module then receives the data from the ET sensor and applies them to the individual fields (zones) of irrigation. The AIS automatically calculates the $E T_{c}$ for local microclimates, based on the modified Penman equation (Allen et al., 1998), and automatically alters their irrigation schedules on a daily basis.

In the CIS, the climatic data were gathered from the weather station, and the daily reference evapotranspiration rate $\left(E T_{\mathrm{o}}\right)$ was calculated and used in making irrigation decisions. Then, the calculated $E T_{\mathrm{o}}$ data were integrated with the crop coefficient $K_{c}$, to determine how much irrigation water should be added. Once the water demand had been determined, the required operational time was applied to start a daily-based irrigation schedule on the wheat and tomato crops (Eq. 1).

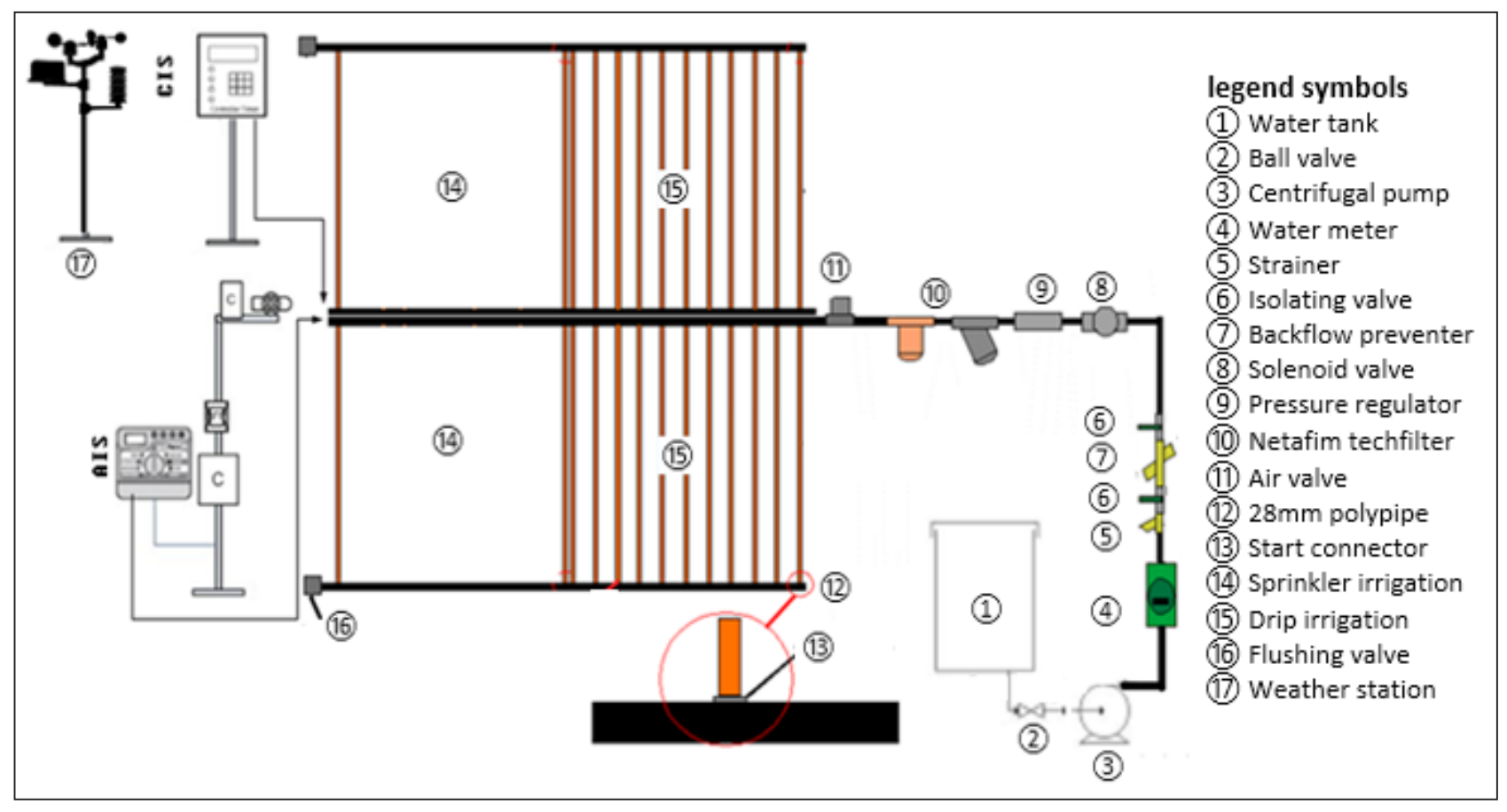

Figure 1

Schematic design of the experimental field (not to scale) 


$$
T_{i}=\frac{E T_{O} \times K_{c} \times A_{p} \times P_{w}}{E_{a}(1-L R) \times Q_{s}}
$$

Here, $T_{\mathrm{i}}$ the is irrigation time (min), $E T$ is the reference evapotranspiration $\left(\mathrm{mm} \cdot \mathrm{day}^{-1}\right), K_{\mathrm{c}}$ is the crop coefficient, $A p$ is block area $\left(\mathrm{m}^{2}\right), P_{\mathrm{w}}$ is a wetted area percentage (\%), $E a$ is irrigation system efficiency, $L R$ is leaching requirements (\%), and $Q s$ is irrigation system discharge $\left(\mathrm{L} \cdot \mathrm{min}^{-1}\right)$.

The AIS was used to irrigate the wheat and tomato crops under both the sprinkler and drip irrigation systems. The daily wheat and tomato $E T_{c}$ data were monitored and recorded. For the CIS, the daily $E T_{\mathrm{o}}$ measurements were multiplied by adequate crop coefficients to provide $E T_{c}$, and were used to efficiently schedule the automated sprinkler and drip irrigation systems.

\section{Agronomic practices and observations}

The two wheat (Triticum aestivum var. Yecora Rojo) crops were sown on 9 December 2013 and 4 December 2014. The seeding rate was $180 \mathrm{~kg} \cdot \mathrm{ha}^{-1}$ with a distance of $20 \mathrm{~cm}$ between rows. The other cultivation practices were carried out according to a given scheduling program. The irrigation processes were terminated on 9 April 2014 and 14 April 2015 for the first and the second season, respectively. Fertilisers containing nitrogen, phosphorus, potassium and other elements were applied at the rate of 100 $\mathrm{kg} \cdot \mathrm{ha}^{-1}$ to both wheat plots. At wheat maturity, measurements were obtained on grain yield $(G Y)$, biomass yield $(B Y)$, and plant height $(P H)$. Grain and biomass yields were determined from test units of 5 rows $\times 1 \mathrm{~m}\left(1 \mathrm{~m}^{2}\right)$. The harvest index $(H I)$ was calculated as grain yield/biomass yield. The grain yield was estimated as the weight of clean grain (as obtained from 7 random samples of $1 \mathrm{~m}^{2}$ and converted to grain yield per hectare). The average grain weight was calculated from 1000 random samples from the harvested plants of each treatment. Plant height was measured at maturity as the distance from the soil surface to the top of the main spike, excluding the awns.

Tomato plants (Solanum lycopersicum Mill. var. Nema) were transplanted to the fields on 14 February 2013 and 7 February 2014. The seedlings were planted in a single row in each bed, with a row spacing of $0.8 \mathrm{~m}$ and an interplant space of $0.4 \mathrm{~m}$ per row. Other cultivation practices were performed, following a scheduled tomato crop programme. The last irrigation was on 31 May 2013 and 27 May 2014 for the first and the second season, respectively. Fruit yield and its components were evaluated in 8 plants from the central plot rows during the harvest period. Other agronomic parameters, such as the total fruit yield, were recorded for each plot to obtain the gross yield $\left(\mathrm{t} \cdot \mathrm{ha}^{-1}\right)$.

The AIS and CIS treatments required the input of the daily and weekly $E T_{c}$ rates of the wheat and the tomato crops during the growing seasons; hence, the irrigation water depths $\left(D_{\mathrm{g}}\right)$ and the accumulative depths added to the wheat and tomato crops during the two treatments were monitored by flow meters, and were recorded throughout the growing season. The data pertaining to the quantities of irrigation water, plant growth, and productivity were gathered daily in special forms prepared for this purpose. During the growing season, the data were analysed directly.

\section{Operation time required for each field}

To calculate the $E T_{c}$ and the irrigation water requirements of the wheat and tomato crops, the daily $E T_{\text {o }}$ values were first determined using the meteorological station data; and these were then multiplied by the crop coefficients and the water application efficiency. Hence, by knowing the area of each wheat field $\left(216 \mathrm{~m}^{2}\right)$ and the discharge rate from the eight sprinklers $\left(4.88 \mathrm{~m}^{3} \cdot \mathrm{h}^{-1}\right)$, the water quantity added at each specific irrigation event could be determined. Based on the area of the tomato field $\left(86.4 \mathrm{~m}^{2}\right)$ and the discharge rate from the drippers $\left(4 \mathrm{~L} \cdot \mathrm{h}^{-1}\right)$, the required water quantity per event, as well as the actual operation time required, could be determined. Thus, the actual operation time required was calculated. In the control fields, the irrigation system was turned on and off manually in the CIS plots. The irrigation applied depth $\left(D_{\mathrm{g}}\right)$ for the AIS for the sprinkler and the drip irrigation was calculated from the differences in the flow meter readings before and after irrigation.

\section{Water use efficiencies}

The irrigation water use efficiency (IWUE) was calculated as the ratio between the grain yield and the seasonal applied irrigation water (Michael, 1978). Water use efficiency (WUE) was the relationship between the grain yield and the $E T_{c}$ (Wanga et al., 2007). Thus, WUE was calculated as the grain yield $(\mathrm{kg})$ per unit land area $\left(\mathrm{Y}, \mathrm{kg} \cdot \mathrm{m}^{-2}\right)$ divided by the units of water consumed by the crop per unit land area $\left(E T_{\mathrm{c}}, \mathrm{m}^{3} \cdot \mathrm{m}^{-2}\right.$, usually reported in $\mathrm{mm}$ ) to produce that yield. Thus, WUE is presented in $\mathrm{kg} \cdot \mathrm{m}^{-3}$, and crop evapotranspiration $E T_{\mathrm{c}}$ is expressed as water depth ( $\mathrm{mm}$ ). Another key parameter for evaluating system efficiency is the irrigation water use efficiency (IWUE, $\mathrm{kg} \cdot \mathrm{m}^{-3}$ ). The WUE and IWUE were calculated using Eqs 2 and 3, respectively.

$$
\begin{aligned}
& I W U E=\left(\frac{Y}{(D g)_{t}}\right) \\
& W U E=\left(\frac{Y}{E T c}\right)
\end{aligned}
$$

where $Y$ is the grain and fruit yield $\left(\mathrm{kg} \cdot \mathrm{m}^{-2}\right), E T_{\mathrm{c}}$ is the evapotranspiration $(\mathrm{mm})$, and $(D g)_{\mathrm{t}}$ is the seasonal irrigation depth (mm).

\section{Statistical analysis}

The data obtained from the two growing seasons were tabulated and subjected to an analysis of variance. A $t$-test was employed to compare the averages of the two methods following a normal distribution. This test was conducted to determine whether there were significant differences between the results of the AIS and CIS treatments.

\section{RESULTS}

\section{Meteorological conditions}

The $E T_{\mathrm{o}}$ rates for the tomato control experiment were measured by the automatic weather station, which was similar to the wheat control treatment using the modified Penman Method, FAO version. The overall climate in the study area is arid, and the area experiences very little rainfall, particularly during summer; however, it receives a fair amount of rain in March and April. 

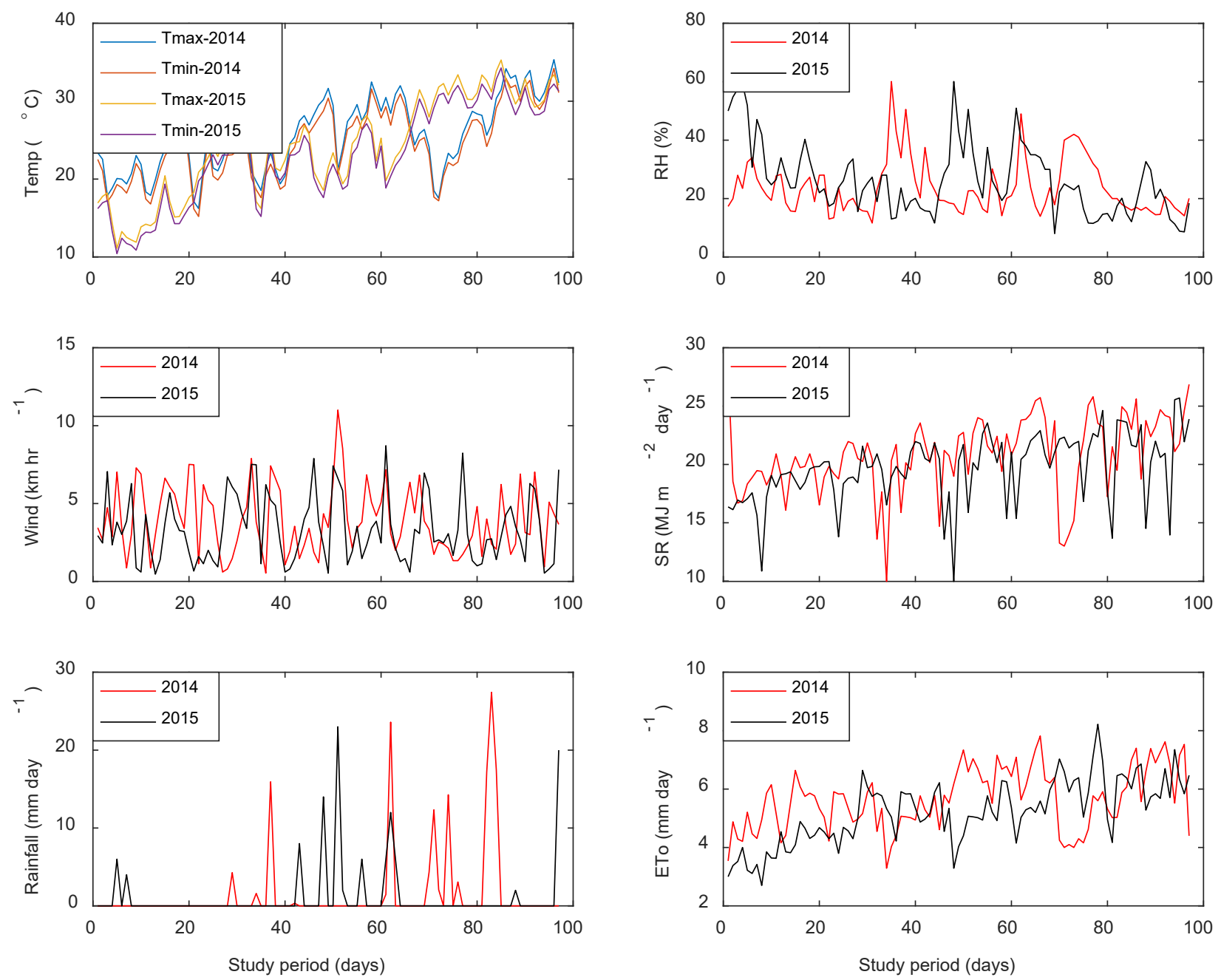

Figure 2

Average daily values of climatic conditions at the experimental site during the growing cycle of tomato and wheat crops in 2014 and 2015

The average annual precipitation ranges from $80 \mathrm{~mm}$ to $140 \mathrm{~mm}$. The relative humidity $(\mathrm{RH})$ is very low and the skies are mostly clear. High temperatures and low precipitation, together with the high variability of both factors, increase evapotranspiration, reduce soil moisture, and damage the soil through mechanical weathering. The averages of air temperature, relative humidity, wind speed, sunshine duration, total precipitation, and reference evapotranspiration $\left(E T_{\mathrm{o}}\right)$ were monitored via an in-situ meteorological station (Fig. 2).

\section{Evapotranspiration $(E T)$}

The processor-interfaced AIS was used as an electronic controller to monitor and record the $E T_{\mathrm{o}}$ based on the measured weather parameters, and based on these measurements to automatically adjust the amount of irrigation water applied. The daily and weekly estimated averages of the $E T_{\mathrm{c}}$ rates for the wheat and tomato crops under the AIS and CIS treatments, which were calculated using the daily records during the two growing seasons, are shown in Fig. 3. The $E T_{\mathrm{c}}$ for the control sample wheat was higher than the $E T_{\mathrm{c}}$ for the AIS sample during the entire growing season, particularly for the 3 weeks before harvesting. Clearly, the $E T_{c}$ values were low in the first 3 weeks under the AIS treatment, and then increased as the plants developed, peaking at approximately $70-105$ days (10-15 weeks) after sowing. In the case of the CIS, the $E T_{c}$ decreased gradually with the senescence of leaves, specifically during Weeks 16 to 19 ; a similar trend occurred for the AIS during the rest of the season.

From Fig. 3, it can be observed that the total $E T$ values for tomato crops under the AIS and CIS treatments were $540.42 \mathrm{~mm}$ and $671.57 \mathrm{~mm}$, respectively. Furthermore, the AIS treatment used $20 \%$ less water than the CIS treatment. The $E T_{c}$ values during the first 4 weeks of crop growth were lower under the AIS treatment, then increased as the plants bloomed and developed, peaking at approximately 55 days ( 8 weeks) post-transplantation. After this point, the $E T_{c}$ values began to gradually decrease with leaf senescence, most significantly during Weeks 9 to 15 ; a similar trend occurred with the CIS management. 

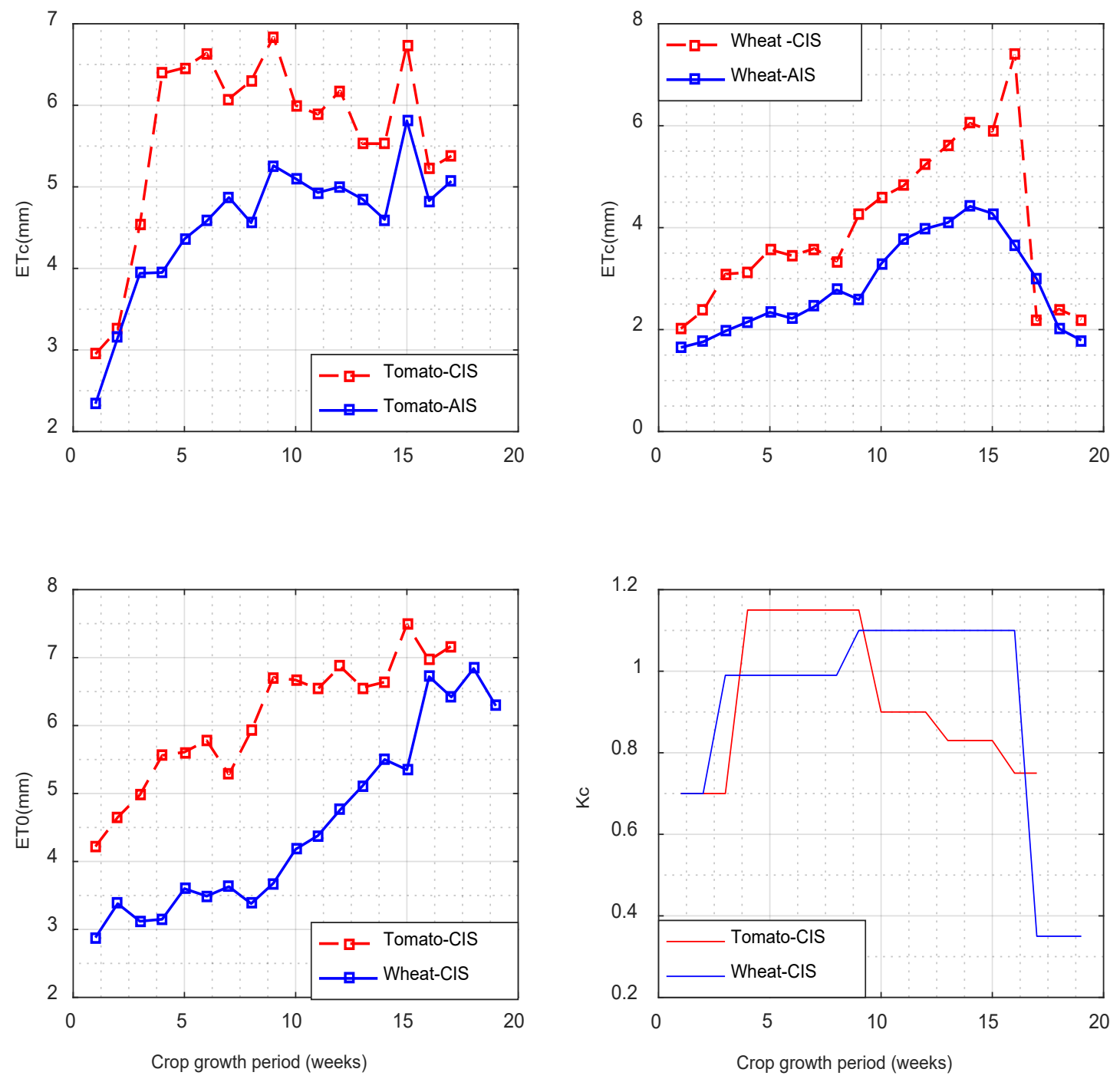

Figure 3

Average weekly ETC, ETo, and Kc rates of wheat and tomato crops during the two seasons for both systems

\section{Irrigation management}

Irrigation events were initiated and terminated according to the data collected and processed by the AIS. This system was equipped with special options, such as the addition of more or less water depending on the needs of the plants. The water quantities and the timing of the irrigation were monitored and recorded, and displayed on the system monitor. The ET values for the CIS were determined using the modified Penman method, FAO-56 version (Allen et al., 1998), to efficiently schedule irrigation at different growth stages.

In terms of wheat crop growth, the stages identified in the study were the initial, the crop wheat development, the midseason, and the late season. Based on local experience, stage durations were approximately 15, 30, 60 and 25 days, and were evaluated via the $K_{c}$. The comparison of the total $E T_{c}$ of the AIS $(382.0 \mathrm{~mm})$ and the CIS experiments $(526.28 \mathrm{~mm})$ shows that the overall difference was quite significant. Fig. 3 also shows that the $E T$ for the CIS experiment was higher than that of the AIS, although the trends were similar throughout the entire growth season. As shown in Fig. 3, under smart irrigation, the $E T$ value was $27 \%$ less than in the control experiment. Fig. 4 shows the average weekly amount of irrigation water $\left(D_{g}\right)$ supplied to the wheat crop under the AIS and the CIS treatments; the average weekly amounts of irrigation water applied to the wheat for the two seasons was $444.76 \mathrm{~mm}$ under the AIS treatment and 600.34 $\mathrm{mm}$ under the CIS treatment. These amounts are less than the amount of irrigation water currently used by the local farmers in the area. The $D_{\mathrm{g}}$ applied under the AIS treatment was $26 \%$ less than that applied under the CIS treatment. In addition, Fig. 4 illustrates the weekly accumulative irrigation water used in the wheat fields during the crop growing seasons for both systems.

In terms of tomato crop growth, the stages identified were the initial, the tomato crop development, the mid-season, and the late-season stage. Based on local experience, these stages were approximately $30,40,40$ and 25 days in duration, respectively, and were evaluated via the $K$. Moreover, as shown in Fig. 3, the $E T_{c}$ for the CIS treatment was higher than that of the AIS treatment; however, they had a similar trend throughout the entire growing season. Figure 4 shows the average amount of 

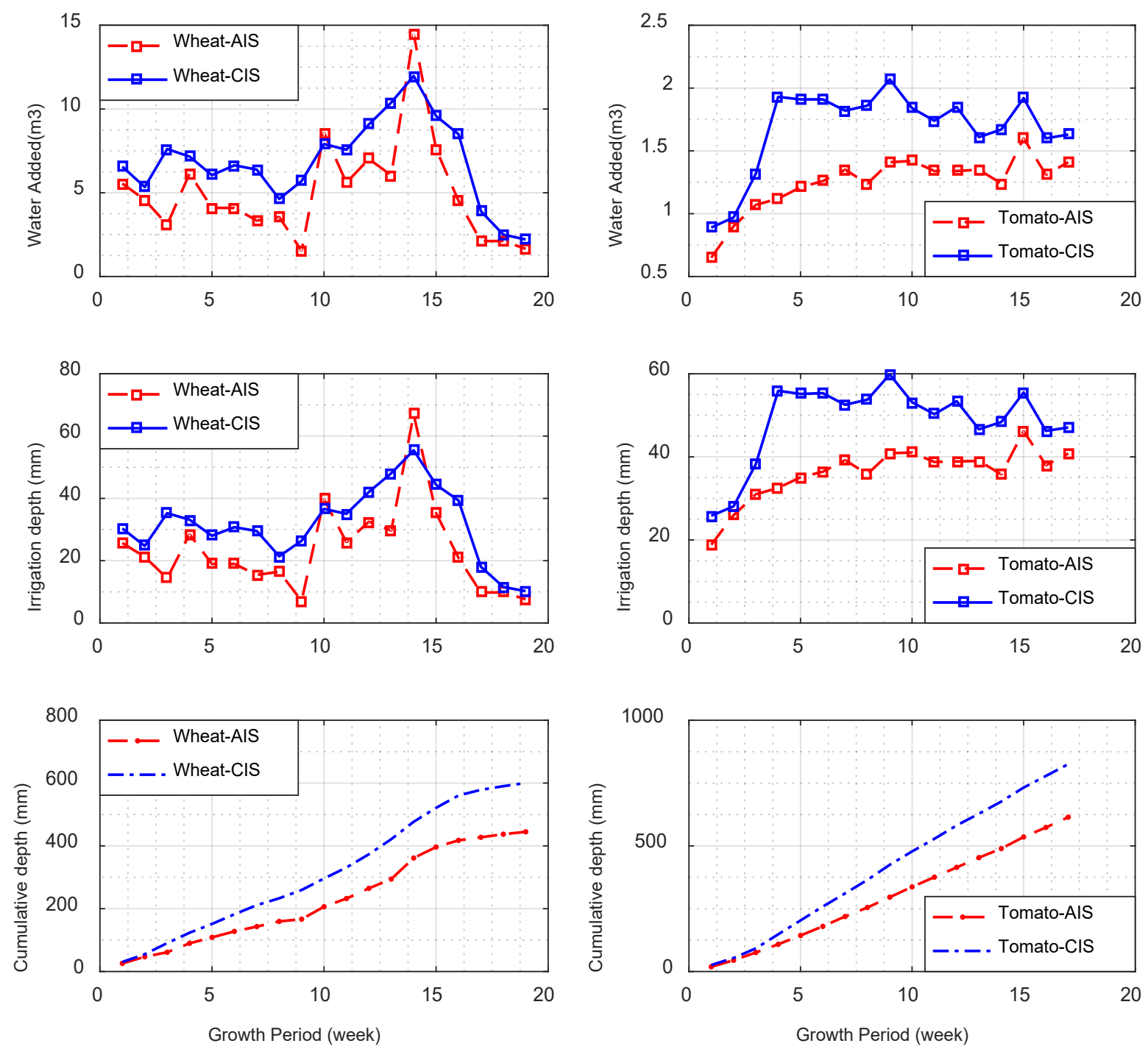

Figure 4

Average irrigation water and cumulative depths added to the wheat and tomato crops via the smart and control systems during the two seasons

weekly irrigation water $\left(D_{\mathrm{g}}\right)$ used in both treatments; the average weekly total irrigation water used during the two growing seasons was $614.26 \mathrm{~mm}$ under the AIS treatment and $825.47 \mathrm{~mm}$ under the CIS treatment, with $26 \%$ less water used in the AIS treatment. Therefore, the results of this study show that the AIS conserves a significant amount of water compared to the CIS. Moreover, the analyses revealed that the $E T_{c}$ values were close at the initial developmental stages; however, their values gradually diverged over the rest of the season.

\section{Analysis of agronomical characteristics}

The effect of the AIS scheduling on wheat and tomato growth, as well as productivity parameters was investigated. The growth characteristics of wheat plants grown during the 2013-2014 and 2014-2015 seasons and the average combined analyses are listed in Table 2. The results of this study revealed that the CIS had a clear effect on the agronomical characteristics of wheat, such as average plant height, which was $75.63 \mathrm{~cm}$ and $65.13 \mathrm{~cm}$ for the CIS and AIS, respectively. The average biological yields and average grain yields of the wheat crop were $17.31 \mathrm{t} \cdot \mathrm{ha}^{-1}$ and $14.61 \mathrm{t} \cdot \mathrm{ha}^{-1}$ for the CIS and $6.83 \mathrm{t} \cdot \mathrm{ha}^{-1}$ and $5.53 \mathrm{t} \cdot \mathrm{ha}^{-1}$ for the AIS, respectively. The average 1000 -kernel weights and average spike length of the wheat crop were $40.77 \mathrm{~g}$ and $9.5 \mathrm{~cm}$ for the CIS and $48.17 \mathrm{~g} 10.4 \mathrm{~cm}$ for the AIS, respectively.

The growth characteristics of the tomato plants grown during the two seasons (2013 and 2014) are presented in Table 2. The AIS had a clear effect on the agronomical plant characteristics. The average plant heights were $45.3 \mathrm{~cm}$ and $38.8 \mathrm{~cm}$ for the AIS and CIS treatments, respectively. The average branch numbers were 6.31 and 5.05 per plant for the same treatments, and the average yields for the two seasons were $39.55 \mathrm{t} \cdot \mathrm{ha}^{-1}$ and 37.05 t.ha ${ }^{-1}$ for the AIS and CIS, respectively. The AIS was superior to the CIS in terms of plant height, number of branches, fruit length, average fruit weight, early yield, WUE and IWUE, by $16 \%, 26 \%, 11 \%, 6 \%, 8 \%, 38 \%$, and $43 \%$, respectively. In addition, the tomato yields varied between treatments by $7-9 \%$ in favour of the AIS. 


\begin{tabular}{|c|c|c|c|c|c|c|}
\hline \multicolumn{7}{|c|}{$\begin{array}{c}\text { TABLE } 2 \\
\text { Responses of wheat and tomato yields (WUE) and water use efficiencies (IWUE) for the two irrigation systems (AIS and CIS) in } \\
\text { the two seasons }\end{array}$} \\
\hline \multicolumn{7}{|c|}{ Wheat treatments } \\
\hline \multirow{2}{*}{ Character } & \multicolumn{2}{|c|}{ First season } & \multirow{2}{*}{ t- sign } & \multicolumn{2}{|c|}{ Second season } & \multirow{2}{*}{ t- sign } \\
\hline & SIS & CIS & & SIS & CIS & \\
\hline Grain yield (GY) & 5.07 & 6.10 & $* *$ & 5.98 & 7.56 & $* *$ \\
\hline Biological yield (BY) & 13.35 & 16.02 & $* *$ & 15.87 & 18.60 & $* *$ \\
\hline Harvest index (HI) & 0.38 & 0.38 & Ns & 0.40 & 0.38 & Ns \\
\hline 1 000-kernel weight $(\mathrm{KW})$ & 39.12 & 47.68 & $* *$ & 42.42 & 48.66 & $* *$ \\
\hline Plant height (PH) & 49.50 & 66.25 & $* *$ & 80.80 & 85.0 & ns \\
\hline Spike length (SPL) & 9.50 & 10.00 & $* *$ & 9.50 & 10.88 & $* *$ \\
\hline WUE $\left(\mathrm{k} \cdot \mathrm{gm}^{-3}\right)$ & 1.27 & 1.13 & $* *$ & 1.64 & 1.47 & $* *$ \\
\hline \multicolumn{7}{|c|}{ Tomato treatments } \\
\hline Plant height $(\mathrm{cm})$ & 44.0 & 39.0 & $* *$ & 46.7 & 38.7 & $* *$ \\
\hline Number of branches & 6.0 & 5.0 & $* *$ & 6.63 & 5.10 & $* *$ \\
\hline Fruit length $(\mathrm{cm})$ & 6.3 & 5.7 & $* *$ & 7.1 & 6.3 & $* *$ \\
\hline Fruit diameter $(\mathrm{cm})$ & 4.6 & 4.8 & $* *$ & 5.8 & 5.1 & $* *$ \\
\hline Fruit shape index & 1.23 & 1.31 & $*$ & 1.22 & 1.30 & $*$ \\
\hline Avg. fruit wt. (g) & 95.0 & 93.0 & $* *$ & 93 & 84 & $* *$ \\
\hline Early yield $\left(\mathrm{t} \cdot \mathrm{ha}^{-1}\right)$ & 23.60 & 24.00 & $* *$ & 26.52 & 22.60 & $* *$ \\
\hline Total yield (t.ha ${ }^{-1)}$ & 39.00 & 37.40 & $*$ & 40.08 & 36.71 & $* *$ \\
\hline WUE $\left(\mathrm{kg} \cdot \mathrm{m}^{-3}\right)$ & 7.50 & 5.72 & $* *$ & 7.15 & 5.33 & $* *$ \\
\hline IWUE $\left(\mathrm{kg} \cdot \mathrm{m}^{-3}\right)$ & 6.56 & 4.70 & $* *$ & 6.32 & 4.30 & $* *$ \\
\hline
\end{tabular}

${ }^{*},{ }^{*} t$ is significant at 0.05 and 0.01 , respectively; $n s=$ not significant

\section{Water use efficiency}

Table 3 presents the effects of the AIS and the CIS on wheat water use efficiency. The WUE and IWUE values were higher for the AIS than for the CIS, i.e., $1.27 \mathrm{~kg} \cdot \mathrm{m}^{-3}$ and $1.12 \mathrm{~kg} \cdot \mathrm{m}^{-3}$ in the first season, respectively, whereas the corresponding values for the second season were $1.64 \mathrm{~kg} \cdot \mathrm{m}^{-3}$ and $1.37 \mathrm{~kg} \cdot \mathrm{m}^{-3}$ respectively. The wheat yields under the AIS treatment increased from 5.07 $\mathrm{t} \cdot \mathrm{aa}^{-1}$ in the first season to $5.98 \mathrm{t} \cdot \mathrm{ha}^{-1}$ in the second season, and a similar trend was also noticed for the WUE and IWUE. The minimum and maximum values for the WUE were $1.13 \mathrm{~kg} \cdot \mathrm{m}^{-3}$ and $1.64 \mathrm{~kg} \cdot \mathrm{m}^{-3}$ in the first and second season, respectively, under the two treatments, indicating that the water was used most effectively in the AIS treatment. The results presented in Table 6 also show that the highest value of IWUE $\left(1.37 \mathrm{~kg} \cdot \mathrm{m}^{-3}\right)$ was obtained from the AIS treatment, whereas the lowest value $\left(1.06 \mathrm{~kg} \cdot \mathrm{m}^{-3}\right)$ was recorded in the CIS during the first season. The difference between the IWUE for the two treatments increased from $6 \%$ to $22 \%$ between Season 1 and Season 2.

Table 3 shows the effects of the AIS and CIS on tomato water use efficiency during the growing seasons. We found that the WUE and IWUE values were higher in the AIS treatment. For instance, the values during the first and second seasons for the AIS and CIS treatments were 7.50 and $6.56 \mathrm{~kg} \cdot \mathrm{m}^{-3}$, and 7.15 and $6.32 \mathrm{~kg} \cdot \mathrm{m}^{-3}$, respectively. The tomato yields in the AIS treatment were $39 \mathrm{t} \cdot \mathrm{ha}^{-1}$ in Season 1 and $40.08 \mathrm{t} \cdot \mathrm{ha}^{-1}$ in Season 2; a similar trend was observed for the WUE and the IWUE. Moreover, the amount of applied irrigation water was $5947.6 \mathrm{~m}^{-3} \cdot \mathrm{h}^{-1}$ in Season 1 and $6337.6 \mathrm{~m}^{-3} \cdot \mathrm{h}^{-1}$ Season 2 (Table 3). Consequently, the maximum and minimum values of WUE were 7.50 and 5.33 $\mathrm{kg} \cdot \mathrm{m}^{-3}$. Overall, the results indicated that irrigation water was used more effectively in the AIS treatment.

Table 3 also shows that the highest and lowest values of IWUE were $6.56 \mathrm{~kg} \cdot \mathrm{m}^{-3}$ and $4.30 \mathrm{~kg} \cdot \mathrm{m}^{-3}$, obtained with the AIS and CIS, respectively. The comparison of the AIS with the CIS shows that IWUE was 39\% higher in the AIS in the 2013 season and $47 \%$ higher in the AIS in the 2014 season. In contrast, the smallest amount of irrigation water used was $594.76 \mathrm{~mm}$ in the AIS treatment, whereas the largest amount applied was 854.79 $\mathrm{mm}$ in the conventional CIS treatment.

\section{Statistical analysis of agronomical factors}

A t-test clearly showed the strong influence of the AIS technique on wheat and tomato agronomical crop factors in both years. The results also demonstrated the strong influence of the CIS treatment on wheat yields and agronomical factors in both years. The results indicate that CIS treatment has a highly significant effect on average plant height $(\mathrm{cm})$, spike length $(\mathrm{cm})$, average kernel weight $(\mathrm{g})$, total biological yield $\left(\mathrm{t} \cdot \mathrm{ha}^{-1}\right)$, and total grain 


\begin{tabular}{|c|c|c|c|c|c|c|c|c|c|c|c|c|}
\hline \multicolumn{13}{|c|}{$\begin{array}{cc}\text { TABLE } 3 \\
\text { Effects of the AIS and CIS on wheat and tomato water }\end{array}$} \\
\hline \multirow{3}{*}{$\begin{array}{l}\text { Irrigation } \\
\text { treatments }\end{array}$} & \multicolumn{6}{|c|}{ Wheat crop } & \multicolumn{6}{|c|}{ Tomato crop } \\
\hline & \multicolumn{2}{|c|}{ ETc } & \multicolumn{2}{|c|}{ AIW } & \multirow{2}{*}{$\frac{\text { WUE }}{\left(\mathrm{kgm}^{-3}\right)}$} & \multirow{2}{*}{\begin{tabular}{|l} 
IWUE \\
$\left(\mathrm{kgm}^{-3}\right)$
\end{tabular}} & \multicolumn{2}{|c|}{ ETc } & \multicolumn{2}{|c|}{ AIW } & \multirow{2}{*}{\begin{tabular}{|c|} 
WUE \\
$\left(\mathrm{kgm}^{-3}\right)$
\end{tabular}} & \multirow{2}{*}{\begin{tabular}{|l} 
IWUE \\
$\left(\mathrm{kgm}^{-3}\right)$
\end{tabular}} \\
\hline & $(\mathrm{mm})$ & $m^{-3} h^{-1}$ & $(\mathrm{~mm})$ & $\mathrm{m}^{-3} \mathrm{~h}^{-1}$ & & & $(\mathrm{~mm})$ & $m^{-3} h^{-1}$ & $(\mathrm{~mm})$ & $m^{-3} h^{-1}$ & & \\
\hline & \multicolumn{6}{|c|}{ 2013-2014 growing season } & \multicolumn{6}{|c|}{ 2013-2014 growing season } \\
\hline AIS & 400.06 & 4000.56 & 453.29 & 4532.90 & 1.27 & 1.12 & 520.30 & 5203 & 594.76 & 5947.60 & 7.50 & 6.56 \\
\hline CIS & 538.25 & 5382.53 & 573.51 & 5735.06 & 1.13 & 1.06 & 653.70 & 6537 & 796.15 & 7961.50 & 5.72 & 4.70 \\
\hline & \multicolumn{6}{|c|}{ 2014-2015 growing season } & \multicolumn{6}{|c|}{ 2014-2015 growing season } \\
\hline AIS & 363.94 & 3639.43 & 364.23 & 4362.30 & 1.64 & 1.37 & 560.50 & 5605 & 633.76 & 6337.6 & 7.15 & 6.32 \\
\hline CIS & 514.31 & 5143.07 & 627.17 & 6271.75 & 1.47 & 1.21 & 689.20 & 6891.80 & 854.79 & 8547.9 & 5.33 & 4.30 \\
\hline
\end{tabular}

yield $\left(\mathrm{t} \cdot \mathrm{ha}^{-1}\right)$; however, there was no significant effect on the harvest index (HI). The AIS had a much more significant effect on the average WUE and the IWUE than the CIS treatment (Table 2). Over the two seasons, the WUE of both the AIS and CIS ranged from 1.13 to $1.64 \mathrm{~kg} \cdot \mathrm{m}^{-3}$, and the IWUE of both treatments ranged from 1.06 to $1.37 \mathrm{~kg} \cdot \mathrm{m}^{-3}$. The results presented in Table 3 also show that both efficiencies were better under the AIS treatment than under the CIS treatment. The maximum values of WUE, $1.64 \mathrm{~kg} \cdot \mathrm{m}^{-3}$ in Season 1 and $1.27 \mathrm{~kg} \cdot \mathrm{m}^{-3}$ in Season 2 , were obtained under the AIS treatment, whereas the minimum values, $1.47 \mathrm{~kg} \cdot \mathrm{m}^{-3}$ in Season 1 and $1.13 \mathrm{~kg} \cdot \mathrm{m}^{-3}$ in Season 2, were obtained from the CIS treatment. Similarly, the maximum values of IWUE were $1.37 \mathrm{~kg} \cdot \mathrm{m}^{-3}$ in Season 1 and $1.12 \mathrm{~kg} \cdot \mathrm{m}^{-3}$ in Season 2 under the AIS treatment, whereas the minimum IWUE values were $1.06 \mathrm{~kg} \cdot \mathrm{m}^{-3}$ in Season 1 and $1.21 \mathrm{~kg} \cdot \mathrm{m}^{-3}$ Season 2 under the CIS treatment.

For the tomato crop, in both seasons, the CIS treatment used more irrigation water than the AIS treatment. The data suggest that the AIS technique had a highly significant effect on the average fruit weight; however, there was no such effect on either the fruit diameter $(\mathrm{cm})$ or the fruit shape. The agronomical data for the AIS treatment also revealed significant differences in plant height $(\mathrm{cm})$, branch number, fruit length $(\mathrm{cm})$, average fruit weight $(\mathrm{g})$, total yield $\left(\mathrm{kg} \cdot \mathrm{m}^{-2}\right)$, total yield $\left(\mathrm{t} \cdot \mathrm{ha}^{-1}\right)$, and WUE/IWUE $\left(\mathrm{kg} \cdot \mathrm{m}^{-3}\right)$ compared to the control. The WUE ranged from 5.53 to $7.33 \mathrm{~kg} \cdot \mathrm{m}^{-3}$ and the IWUE ranged from 4.50 to $6.44 \mathrm{~kg} \cdot \mathrm{m}^{-3}$ over the two seasons. The results presented in Tables 2 and 3 show that both efficiencies were higher under the AIS than under the CIS. The maximum values of WUE (7.50 and $7.15 \mathrm{~kg} \cdot \mathrm{m}^{-3}$ ) were obtained with the AIS treatment, whereas the minimum values $\left(5.72\right.$ and $5.33 \mathrm{~kg} \cdot \mathrm{m}^{-3}$ ) were obtained with the CIS treatment, indicating that water was used more effectively in the AIS.

The IWUE was higher for the AIS treatment than for the CIS treatment. The maximum values of IWUE ( 6.56 and 6.32 $\mathrm{kg} \cdot \mathrm{m}^{-3}$ for the first and second season) were obtained with the AIS, whereas the minimum values $\left(4.70\right.$ and $4.30 \mathrm{~kg} \cdot \mathrm{m}^{-3}$ for the first and the second season) were obtained with the CIS. In the 2010 season, the IWUE was $29 \%$ higher under the AIS treatment than under the CIS treatment, and in the 2013 season it was
32\% higher under the AIS treatment. Thus, the WUE and IWUE values decreased as more irrigation water was applied (Table 3 ). Furthermore, the higher respective values ( 7.50 and $4.75 \mathrm{~kg} \cdot \mathrm{m}^{-3}$ ) in the first season were achieved with the AIS treatment, whereas the corresponding values for the second season were 7.15 and $4.30 \mathrm{~kg} \cdot \mathrm{m}^{-3}$.

\section{DISCUSSION}

The AIS sprinkler irrigation treatment (wheat) used $27 \%$ less irrigation water than the CIS treatment. In the drip irrigation treatment (tomato), the AIS used 26\% less water than the CIS. The efficiency of the AIS may be due to its ability to supply either more or less water according to the needs of the plants. Moreover, the analysis showed that the $E T_{c}$ value of the CIS treatment was higher than that of AIS treatment for the entire season, possibly because of the more accurate irrigation scheduling of the AIS, or owing to the near real-time adjustment of the irrigation associated with the AIS, or the fact that the relevant wheat and tomato $K_{c}$ values (Allen et al., 1998) used for the CIS were derived in a different environment from the study site, which leads to higher availability of water in the root zone. The soil distribution could also be responsible for the CIS results, as the field consisted entirely of translocated soil. Furthermore, the differences could be the result of the selected Kc values, which were selected from the literature and were used to predict the $E T$. The results may also reflect the fact that the AIS was designed specifically for landscape irrigation scheduling, although it also yielded satisfactory results when used for wheat crop irrigation. The results of the first and second seasons were consistent within each treatment; however, a significant difference was found between treatments in both seasons.

Starting with an irrigation process at $80 \%$ of $E T_{c}$, the analysis revealed that the $E T_{c}$ value of the control treatment was higher than that of the AIS treatment throughout both seasons, indicating the AIS's effectiveness in providing irrigation water, which is essential in arid regions. Furthermore, this system improved irrigation practices and could, ultimately, minimise labour needs. 
The total applied irrigation water in both systems showed that the change in irrigation frequency, as well as the application stage, could significantly affect the available soil water during the wheat-growing season. This study revealed that both irrigation scheduling techniques, either involving sprinkler or drip irrigation, have a clear effect on the agronomical characteristics of plants.

There were variations in the yields of the two crops under the AIS and CIS treatments between the seasons. The CIS resulted in greater yields than the AIS because of the variation in the amount of water added. The increased moisture level in the root zone probably explains the improved agronomical factors, particularly as more irrigation water was added $\left(D_{\mathrm{g}}\right)$ in the CIS treatment. The decrease in soil aeration due to low irrigation water in the AIS treatment may have affected all of the agronomical parameters.

The results indicated that, in both seasons, every $1 \mathrm{~mm}$ of water depth applied by the AIS to the wheat crop produced an average yield of $112.45 \mathrm{~kg} \cdot \mathrm{mm}^{-1}$, and every $1 \mathrm{~mm}$ water depth applied by the CIS produced an average yield of $11.35 \mathrm{~kg} \cdot \mathrm{mm}$ ${ }^{1}$. For the tomato crops, the average values for the two seasons were 64.41 and $44.95 \mathrm{~kg} \cdot \mathrm{mm}^{-1}$, respectively. Hence, the low amount of irrigation water added in the AIS treatment affected all of the agronomical parameters. Each of the cases examined in this study showed a great potential to save water as compared to irrigation methods practiced by the local framers in the area. Conserving water is very important in areas experiencing severe drought, such as Saudi Arabia.

The decrease in WUE and IWUE observed under the CIS treatment can be attributed to the increasing amounts of irrigation water. This agrees with the findings of Almarshadi and Ismail (2011). Similar findings were obtained by Wan and Kang (2006), who found that a low irrigation frequency produced higher water use efficiency than a high irrigation frequency. In this study, the lower amounts of water used under the drip and sprinkler irrigation systems were inversely related to water use efficiency. Hence, it can be concluded that the positive effect of IWUE values under the AIS treatment, resulting in a $26 \%$ decrease in the amount of seasonal irrigation water required (Table 3).

In the AIS, increased yields were obtained with minimal water, which results in a higher IWUE. This finding is consistent with a study by Sammis and Wu (1986), who reported that IWUE increased under soil moisture stress, and is also consistent with the observations of Camp et al. (1989), and Wan and Kang (2006), who reported that low irrigation frequencies result in higher water use efficiency values than high irrigation frequencies. For both seasons, the AIS resulted in higher WUE and IWUE values than the CIS.

The higher water use efficiency under the AIS can be attributed to lower amounts of irrigation water used. In other words, the reduced water consumption results in higher water use efficiency. The variation in WUE was not consistent in the two growing seasons, possibly because of the differences in weather conditions. Overall, the AIS yielded higher WUE and IWUE values that the CIS. It was apparent that the WUE of wheat decreased as more water was used in the irrigation.

\section{CONCLUSIONS}

Through this 2-year field study of 2 irrigation techniques under arid conditions, we found that automated irrigation systems (AIS) offer a significant advantage for irrigating wheat and tomato crops. These irrigation techniques are recommended for irrigating crops in arid regions, owing to their ease of use and to the reduction in water use, as well as for providing the irrigation manager with reliable information. AIS provide a convenient and practical system that meets the agronomic needs of crops, thus contributing to the sustainability of agricultural systems. However, providing the correct installation, operation, maintenance and programming inputs on these controllers using the site-specific parameters is imperative to achieving an appropriate watering level. The agronomical characteristics of the crops grown under these irrigation techniques are considerably superior to those grown under the conventional irrigation control system. Furthermore, the WUE and IWUE are higher under the automated irrigation system. Therefore, the proposed system could be refined to create better and more efficient scheduling control. The results also suggest that scheduling techniques using drip and sprinkler irrigation systems under arid conditions offer an economic benefit owing to the substantial decrease in the applied irrigation water, compared to that applied using the CIS.

\section{ACKNOWLEDGMENTS}

This Project was funded by the National Plan for Science, Technology and Innovation (MAARIFAH), King Abdulaziz City for Science and Technology, Kingdom of Saudi Arabia, Award Number (11-AGR1476-02).

\section{REFERENCES}

ABRAHAM N, HEMA PS, SARITHA EK and SUBRAMANNIAN S (2000) Irrigation automation based on soil electrical conductivity and leaf temperature. Agric. Water Manage. 45 145-147. https://doi. org/10.1016/S0378-3774(99)00078-5

ACEVEDO-OPAZO C, ORTEGA-FARIAS S and FUENTES S (2010)

Effects of grapevine (Vitisvinifera L.) water status on water consumption, vegetative growth and grape quality: an irrigation scheduling application to achieve regulated deficit irrigation. Agric. Water Manage. 97 956-964. https://doi.org/10.1016/j. agwat.2010.01.025

AL-GHOBARI HM (2000) Estimation of reference evapotranspiration for the southern region of Saudi Arabia. J. Irrig. Sci. 19 81-86. https://doi.org/10.1007/s002710050004

ALLEN RG, PEREIRA LS, RAES D and SMITH M (1998) Crop evapotranspiration-guidelines for computing crop water requirements FAO irrigation and drainage. In FAO irrigation and Drainage Paper 56. FAO, Rome. 7-28.

ALMARSHADI M and ISMAIL S (2011) Effects of precision irrigation on productivity and water use efficiency of alfalfa under different irrigation methods in arid climates. J. Appl. Sci. Res. 7 299-308.

ASABE (American Society of Agricultural and Biological Engineers (2007) Standard S436.1. Test procedure for determining the uniformity of water distribution of center pivot and lateral move irrigation machines equipped with spray or sprinkler nozzles. ASABE, St. Joseph, Mich, USA.

CAMP C, SADLER E and BUSSCHER W (1989) Subsurface and alternate middle micro irrigation for the South-eastern Coastal Plain. Trans. ASAE 32 451-456. https://doi.org/10.13031/2013.31025

DABACH S, LAZAROVITCH N, ŠIMŮNEK J and SHANI U (2013) Numerical investigation of irrigation scheduling based on soil water status. Irrig. Sci. 31 27-36. https://doi.org/10.1007/ s00271-011-0289-X

DASSANAYAKE D, DASSANAYAKE H, MALANO G, DUNN DOUGLAS P and LANGFORD J (2009) Water saving through intelligent irrigation in Australian dairy farming: use of intelligent irrigation controller and wireless sensor network. 18th World IMACS/ MODSIM Congress, 13-17 July 2009, Cairns, Australia. 4409-4417. 
DAVIS SL and DUKES MD (2016) Importance of ET controller program settings on water conservation potential. Applied Eng. Agric. 2 251-262.

DUKES M (2012) Water conservation potential of landscape irrigation smart controllers. Trans. ASABE. 5 563-569. https://doi. $\operatorname{org} / 10.13031 / 2013.41391$

DUKES M, ZOTARELLI L and MORGAN K (2010) Use of irrigation technologies for vegetable crops in Florida. Hortic. Technol. 20 133-142.

HAYASHI HA, AKIMOTO K, TOMODA T and KII M (2012) Global evaluation of the effects of agriculture and water management adaptations on the water-stressed population. Mitig. Adapt. Strateg. Glob. Change 18 591-618. https://doi.org/10.1007/s11027-012-9377-3

IRRIGATION ASSOCIATION (2011) Smart water application technology (SWAT) turf and landscape irrigation equipment testing protocol for climatologically based controllers: $8^{\text {th }}$ draft. Falls Church, Va.: Irrigation Association. URL: www.irrigation.org (Accessed 15 October 2011).

KIM Y, EVANS R and IVERSEN W (2008) Remote sensing and control of an irrigation system using a distributed wireless sensor network. IEEE Trans. Instrum. Meas. 57 1379-1387. https://doi.org/10.1109/ TIM.2008.917198

MCCREADY M, DUKES M and MILLER G (2009) Water conservation potential of smart irrigation controllers on St Augustine grass. Agric. Water Manage. 96 1623-1632. https://doi.org/10.1016/j. agwat.2009.06.007

MENDEZ-BARROSO L, PAYAN J and VIVONI E (2008) Quantifying water stress on wheat using remote sensing in the Yaqui Valley, Sonora, Mexico. Agric. Water Manage. 95 725-736. https://doi. org/10.1016/j.agwat.2008.01.016

MERRIAM J and KELLER J (1978) Farm Irrigation System Evaluation: A Guide for Management. Utah State University, Logan, Utah.

MICHAEL AM (1978) Irrigation: Theory and Practice. Vikas Pub. House PVT LTD, New Delhi.

MONTAZAR A and SADEGHI M (2008) Effects of applied water and sprinkler irrigation uniformity on alfalfa growth and hay yield. Agric. Water Manage. 95 1279-1287. https://doi.org/10.1016/j. agwat.2008.05.005

MULAS P (1986) Developments in the automation of irrigation. Colture Protelle 15 17-19.

MUN S, SASSENRATH G, SCHMIDT A, LEE N, WADSWORTH M, RICE B, CORBITT J, SCHNEIDER J, TAGERT M, POTE J and PRABHU R (2015) Uncertainty analysis of an irrigation scheduling model for water management in crop production. Agric. Water Manage. 155 100-112. https://doi.org/10.1016/j.agwat.2015.03.009

MUÑOZ-CARPENA R and DUKES M (2005) Automatic irrigation based on soil moisture for vegetable crops. Extension Bull., ABE356 of the Dept of Agricultural and Biological Engineering, University of Florida, Gainesville. URL: http://edis.ifas.ufl.edu/pdffiles/AE/ AE35400.pdf (Accessed April 2014).

NAUTIYAL M, GRABOW G, MILLER G and HUFFMAN R (2010) Evaluation of two smart irrigation technologies in Cary, North
Carolina. ASABE Annual International Meeting, 20-23 June 2010, Pittsburgh, Pennsylvania.

NORUM M and ADHIKARI D (2009) Smart irrigation system controllers. In: 7th World Congress on Computers in Agriculture Conference Proceedings, 22-24 June 2017, Reno, Nevada. ASABE, St. Joseph, Michigan.

OJHA T, MISHRA S and RAGHUWANSHI NS (2015) Wireless sensor networks for agriculture: The state-of-the-art in practice and future challenges. Comput. Electron. Agric. 118 66-84. https://doi. org/10.1016/j.compag.2015.08.011

PEREIRA L, OWEIS T and ZAIRI A (2002) Irrigation management under water scarcity. Agric. Water Manage. 57 175-206. https://doi. org/10.1016/S0378-3774(02)00075-6

SAMMIS T and WU I (1986) Fresh market tomato yields as affected by deficit irrigation using a micro irrigation system. Agric. Water Manage. 12 117-126. https://doi.org/10.1016/0378-3774(86)90010-7

Schlegel J, Stone L, Dumler T and Lamm F (2012) Managing diminished irrigation capacity with preseason irrigation and plant density for corn production. Trans. ASABE 55 525-531. v

SEZEN S and YAZAR A (2006) Wheat yield response to line-source sprinkler irrigation in the arid Southeast Anatolia region of Turkey. Agric. Water Manage. 81 59-76. https://doi.org/10.1016/j. agwat.2005.04.011

SMARSLY K (2013) Agricultural ecosystem monitoring based on autonomous sensor systems. In: Second International Conference on Agro-Geoinformatics, 12-16, August 2013 Fairfax, Virginia USA). 402-407. https://doi.org/10.1109/ Argo-Geoinformatics.2013.6621952

WAN S and KANG Y (2006) Effect of drip irrigation frequency on radish (Raphanus sativus L.) growth and water use. Irrig. Sci. 24 161-174. https://doi.org/10.1007/s00271-005-0005-9

WHITTLESEY N (2003) Improving irrigation efficiency though technological adoption: when will it conserve water? In: Alsharhan AS and Wood WW (eds) Water Resources Perspectives: Evaluation, Management and Policy. Elsevier Science, Amsterdam. 53-62. https:// doi.org/10.1016/S0167-5648(03)80007-2

YAZAR A, HOWELL A, DUSEK D and COPELAND K (1999) Evaluation of crop water stress index for LEPA irrigated corn. Irrig. Sci. 18 171-180. https://doi.org/10.1007/s002710050059

YILDIRIM M and DEMIREL M (2011) An automated drip irrigation system based on soil electrical conductivity. Philipp Agric. Scientist. 94 343-349.

YILDIRIM M (2010) The performance of irrigation automation system based on soil moisture level for pepper (Capsicum annuum L.) growth. J. Food Agric. Environ. 8 629-634.

ZHANG X, ZOU H, ZHANG N, LI Y and YANG Y (2013) The research and applications of agricultural automation based on Internet of things. Inf. Sci. Manage. Eng. (Set). 46 111-119. https://doi. org/10.2495/isme130151

ZHU D, WU P, MERKLEY G and JIN D (2009) Drip irrigation lateral design procedure based on emission uniformity and field micro topography. Irrig. Drain. 59 1-12. 